\title{
MANAGEMENT OF ECO-TOURISM SITES: A CASE STUDY OF THE AJANTA CAVES
}

\author{
Rajesh Ragde* and Madhuri T. Sawant**
}

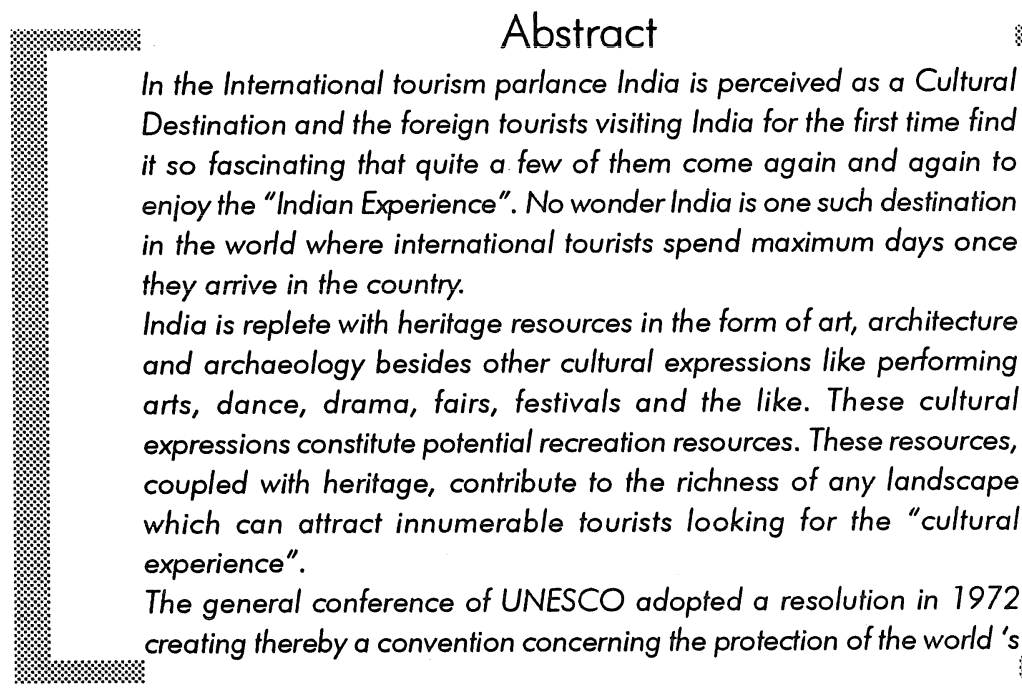

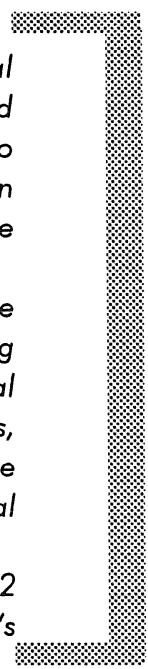

* Sr. Lecturer, Department of Tourism Administration, Dr. Babasaheb Ambedkar Marathwada University, Aurangabad (M.S.)

* UGC JRF, Department of Tourism Administration, Dr. Babasaheb Ambedkar Marathwada University, Aurangabad (M.S.) 

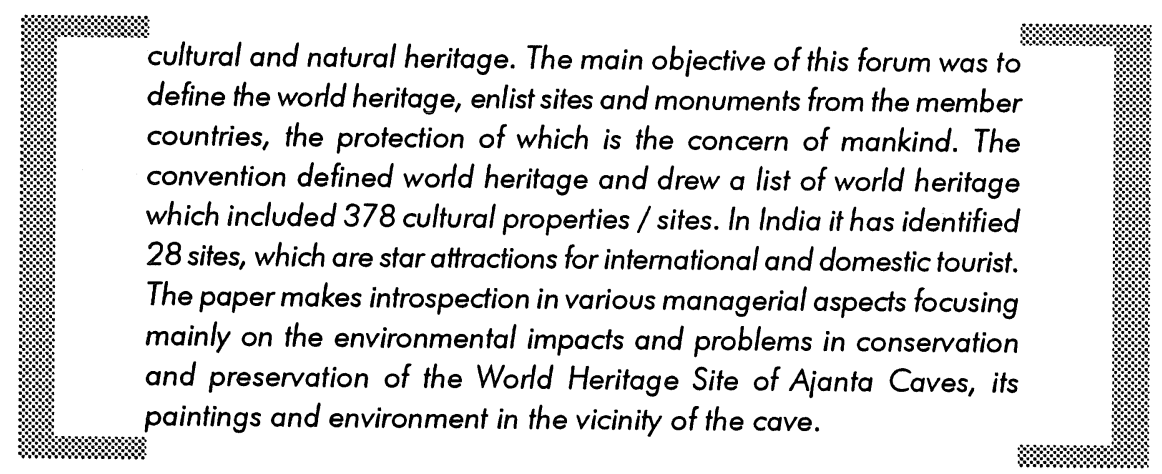

\section{Introduction}

Maharashtra has the distinction of having more than 1000 cave temples that had been excavated between $3^{\text {rd }}$ century B.C. to $12^{\text {th }}$ century A.D., representing different pantheons and religions. Some of the important centres are Pitalkhora, Kondane, Bhaja, Ajanta, Bedsa, Karla, Kanheri, Junnar, Nasik etc. At Ajanta, all 30 caves are excavated in the picturesque setting of a horse shoe valley with a magnificent vertical carp, that are more than $70 \mathrm{mts}$ in height from the river bed of Waghora meandering through the valley. This retreat also provided the monks with enough time for furthering their religious pursuits through intellectual discourses for a considerably longer period particularly during the rainy season "Varsavasa". The earliest caves date back to circa. $2^{\text {nd }}$ century B.C. while the latest to around $7^{\text {th }}$ century A.D. A fragmentary inscription of $8^{\text {th }}-9^{\text {th }}$ century A.D. in front of cave no. 26 indicates that these caves were under occupation during that period.

The caves belong to two different Buddhist sects, viz. Hinayana (the lesser vehicle, in which Buddha was represented in symbolic form) and Mahayana (the greater vehicle, when the image of Buddha was conceived and worshipped). The Hinayana caves (Caves $8-10,12-13$ and 15A) were excavated between circa. $2^{\text {nd }}$ century B.C. and $2^{\text {nd }}-3^{\text {rd }}$ centuries A.D. while the Mahayana caves (Caves 1-7, 11, 14 and $15-30$ ) were excavated between circa. $4^{\text {th }}$ and $7^{\text {th }}$ century A.D. Architecturally the caves at Ajanta can be classified into a vihara (monastery, the residing place of the Buddhist monks combined with a shrine for Buddha in some cases), chaityagriha (the worshipping place of chaitya, the symbolic representation of Buddha), podhis (water cisterns to cater to the need of the monks) and rock cut steps (which once connected the individual caves to the river Waghora). Out of these, five (cave no. 9, 10, 19, 26 and 29) are chaityagrihas and the rest are viharas. 
Ajanta is world famous for not only the caves but for the immense wealth of the most delectable mural paintings which are retained in more than half a dozen caves. The beginning of the paintings date back to pre-Christian era, examples of which can be seen in Caves $9 \& 10$. The artists' brush attained the Zenith during the $5^{\text {th }}-7^{\text {th }}$ centuries A.D. when majority of the caves were painted, the remains of which can be still seen in Caves 1, 2, $16 \& 17$. These paintings are richly embellished, colourful, most exquisite, exhibiting harmony of forms and colour, vividly portrayed, communicative, expressive, the resultant of extreme faith the monks had in Buddha, multiple perspective and conjuring everyone's attention. The subject matter of the paintings deals with various Jatakas (the story related to previous births of Buddha as Bodhisattva). They also depict important events from the miracles performed by Buddha and various floral and faunal motifs, geometrical designs and various other motifs that suggest the forceful brushstrokes and firmness of the outlines. The important paintings associated with the life of Buddha can be seen at Cave 1 (Miracle of Sravasti, manifestation of Buddha into thousand forms), Cave 2 (Birth of Buddha), Cave 16 (Conversion of Nanda), Cave 17 (Subjugation of Nalagiri, the Instigated elephant; Buddha preaching at Tusita heaven; Buddha's visit to Kapilavastu and meeting his wife Yasodhara and son Rahula). The important Jataka stories can be seen at Cave 1 (Sibi, Hamsa, Mahajanaka Jataka), Cave 2 (Vidhurapandita Jataka), Cave 10 (Sibi, Chhaddanta jataka), Cave 17 (Chhaddanta, Mahakapi, Hamsa, Vessantara, Mahaummaga, Matriposaka, Mahisa, Matsya, Mriga Jatakas). Apart from the painted representations of events from Buddha's life sculptural panels of the Great Departure (Buddha leaving Kapilavastu Cave 1), Mirade of Sravasti (Cave 7), Buddha visiting Kapilvastu (Cave 19) and Subjugation of Mara, Mahaparinirvana (Cave 26) are also well represented. The most famous paintings however are the representation of Bodhisattva Padmapani and Vajrapani (Cave 1), flying apsara, toilet scene (Cave 17) etc.

The inscriptions found in some of the caves help us to know about the patronage that these monastic establishments received during its heydays. During the Hinayana period, inscriptions both painted and inscribed are noticed in Cave 9 (painted), 10 (on the façade, on walls and on the pillars few painted records), 12 (one inscribed), all belonging to a time bracket from circa. $2^{\text {nd }}$ century B.C. to $2^{\text {nd }}$ century A.D. An important donative inscription of Varahadeve, the minister of Vakataka king Harisena (A.D. 475-500) is located in Cave 16 dedicated to the order of Buddhist Sangha and in Cave 17 was the gift of a prince (who subjugated Asmaka), feudatory to the same king. In addition to this, painted donatory inscriptions of individuals are also found in Caves 16, 17, etc. An inscription found in Cave 26 records the construction of the chaityagriha due to the efforts 
of one monk Buddhabhadra. A solitary Rastakuta inscription in cave no. 26 establishes the Rastrakuta patronage extended to Ajanta Caves.

The paintings were executed after elaborate preparation of the rock surface initially and then giving two layers of carrier surface to hold the paintings. Over this a plain and smooth layer of lime was given and the paintings were executed over it. The colours and shades provided vary from red and yellow ochre, terra verde (for green colour) lime, kaolin and gypsum (white), lamp black (black) and lapis lazuli (blue). The Ajanta paintings can be defined as tempera and they are not frescoes as it is widely believed.

Ajanta is a monument of many facets and a wealth which cannot be measured by any parameters. This immense quality and character has been recognized by the UNESCO when in its declaration in 1983 had included Ajanta as a World Heritage Monument.

The rock cut temple caves in India have been one of the most glorious part of our culture which comprises an expression of inner urges and cumulative beliefs of people gathered through centuries of experience.

Travel in distant past was not a thing of pleasure as it is today. The caves of Ajanta are located on the ancient trade routes. It is believed that amongst the travelers were the merchant / traders on a very large scale as trade and commerce was the strongest travel motivator in ancient time.

Among the other purposes of visiting caves were for religious purpose, education, leisure, visiting friends and relatives, accommodation, storage of valuables etc.

The modern age concept of travel has not changed on a large scale, most of the tourists visiting caves are artists, nature lovers, geologists, architects, photographers, scholars including religious, cultural academicians etc.

\section{Eco-Tourism at Ajanta Caves}

The conservation and preservation of the caves was also there during ancient time, which was funded by the traders and patronized by the Kings and Emperors. The conservation and preservation aspects have changed in modern age which makes it very crucial to study the most appropriate conservation methods which will not only be beneficial to the monument and its environment. Currently an development project financed by Japan Bank for International Co-operation is being implemented in the Ajanta - Ellora region. The plan for the Ajanta - Ellora 
conservation and development project has been prepared by the Tata Consultancy Services (TCS). The objectives of the Ajanta - Ellora Conservation and Development Project are:

1. To conserve and preserve the monuments and natural resources in AjantaEllora region.

2. To improve the infrastructure in order to accommodate the increasing number of tourists to the region and enhance their experience by providing improved facilities and services.

3. To preserve the historical and cultural background of religions like Buddhism and to highlight the significance of Ajanta and Ellora as well as other related sites.

4. To provide better visitor management service to enrich the overall visitor experience.

5. To motivate tourists to extent their stay in the region, thereby augmenting the country earnings from tourism.

The Special Considerations of Ajanta-Ellora Development Project are ;

1. The fragile nature of the monuments, which need conservation.

2. The paintings which are in a continuous state of decay need to be carefully preserved.

Introducing tourist development without affecting the socio-cultural balance of the local community and yet ensuring that the benefits of the development process reach them.

Table - I (Sub project and Implementing Agencies under AEDP)

\begin{tabular}{|l|l|}
\hline \multicolumn{1}{|c|}{ Sub - Projects } & \multicolumn{1}{c|}{ Implementing Agencies } \\
\hline $\begin{array}{l}\text { Conservation of } \\
\text { Monuments }\end{array}$ & $\begin{array}{l}\text { Archaeological Survey of India, Department of } \\
\text { Culture, Government of India (AIS). }\end{array}$ \\
\hline Afforestation & $\begin{array}{l}\text { Forest Department, Government of Maharashtra } \\
\text { (FDM). }\end{array}$ \\
\hline Aerodrome Facilities & $\begin{array}{l}\text { National Airport Authority, Ministry of Civil } \\
\text { Aviation, Government of India. }\end{array}$ \\
\hline
\end{tabular}




\begin{tabular}{|l|l|}
\hline \multicolumn{1}{|c|}{ Sub - Projects } & \multicolumn{1}{c|}{ Implementing Agencies } \\
\hline Roads & $\begin{array}{l}\text { Public Works Department, Government of } \\
\text { Maharashtra (PWD). }\end{array}$ \\
\hline $\begin{array}{l}\text { Water Supply and } \\
\text { Sewerage }\end{array}$ & $\begin{array}{l}\text { Maharashtra Water Supply and Sewerage Board } \\
\text { (MWSSB). }\end{array}$ \\
\hline Electricity & Maharashtra State Electricity Board (MSEB) \\
\hline $\begin{array}{l}\text { Visitor Management } \\
\text { System }\end{array}$ & $\begin{array}{l}\text { MTDC, ASI, Department of Tourism, } \\
\text { Government of Maharashtra and Government. }\end{array}$ \\
\hline
\end{tabular}

Source :- Maharashtra Tourism Development Corporation.

\section{First Phase of Ajanta - Ellora Development Project}

The first phase of Aianta - Ellora Development Project had commenced in 1992 and was completed in May 1998. In this phase Rs. 82.80 crores was spent on the Infrastructural facilities like upgrading Aurangabad Airport and developing and greening the routes to the caves. The details of the work completed under the subprojects are as follows.

1. Conservation of Monuments (ASI) : In this subproject Rs. 8.60 Million was spent on the improvements to approach path to the Ajanta caves and improvements of the internal roads at Ellora.

2. Afforestation (FDM) : In this subproject Rs. 32.436 Million was spent on tree plantation and fencing of 500 hectares at Ajanta and 237 hectares at Ellora.

3. Water Supply and Sewerage (MWSSB) : In this subproject Rs. 55.8.6 Million has been spent on the water supply pipeline to the proposed Tourist Complex at Ajanta and Ellora.

For the present study an introspection has been made on the plans executed in the first phase of the Development Project. These are:

\section{Zoning Plan}

There is a three way classification of the zones i.e.

i) Protected Area - actual monument area.

ii) Prohibited Area - area within a 3 K.M. radius.

iii) Restricted Area - area within a 10 K.M. radius. 
It is recommended that the sites be further divided into more specific zones to radius some specific activities at the zones.

01. Resource Specific Zones - It includes the monument and the immediate surrounding.

02. Administrations and Service Zones - Offices of ASI, MTDC, Department of Forest and residential area for staff.

03. Commercial and Visitor Activity Zone - Activities like vending and shopping, visitor center, restaurants, auditorium, art and crafts centers.

04. Vegetation Area - the vegetation area is further divided in three zones.

a. Green Zone : Green Zone is used for naturalized playgrounds and picnicking.

b. Scenic Corridor Zone : Scenic corridor zone forms the vegetation, buffer zone, nature trails and hiking trails are part of the zone. and

c. Forestry Zone : Here professionally managed forest are maintained and monitored to control the soil erosion.

Institutional Zone - This zone comprises educational facilities and all archaeological activities relevant to the area.

\section{Vegetation and Landscape Plan}

01. The area above the caves are fenced to prevent livestock grazing, grazing prevents newly planted trees and shrubs from growing. Large trees like banyan, neem and teak is removed from the terrace above the caves.

02. The north facing slope between the viewpoint and the Waghur River is used to create dry deciduous forest, which will be referred as transitional forest as it is in transition from a badly degraded collection of vegetative components to a climax forest with species conducive to soil protection and esthetic value. The trees, shrubs and grasses, which were nature to the area provide an ideal habitat for wildlife are used.

Amongst the species planted here are ; i) Dhavra (Anogeissus Latifolia), ii) Anjan (Hardwickia Binata), iii) Cochlospirmum Religiosum, iv) Sheesham (Dalbergia Latifolia) and v) Buchanonia Lanzan etc. 
Shallow rooted shrubs and grasses are encouraged to prevent soil erosion and protection of caves.

After having done a scientific, native and eco friendly study of the species, the vegetation is done but there must be perfect monitoring and implementation because it will lead to drying of the vegetation and accommodation of the unwanted species.

\section{Conservational Measures at the Monument}

Conservation of paintings at Ajanta.

01. Chemical conservation.

02. Humidity control, a set of double doors are fixed at the entrance.

03. Optic fiber lights are used.

04. A buffer area is established between the visitors and paintings.

05. No of visitors to be left in a cave are reduced.

06. Manual removal of bats in the caves.

\section{Problems of Eco-tourism Management and it's Remedial Measures}

\section{Carrying Capacity}

Carrying capacity inside the cave must be well defined and managed. The harm starts when the tourist enters into the cave.

i. The tourists remove their foot wear outside and enter the cave, taking along with them a number of various micro-organisms which get into the cave and get collected on the paintings. A deep research must be done with the help of experts in microbiology and appropriate measures must be taken.

ii. Breathing of the tourist causes direct effect on painting. The paintings contain calcium bicarbonate and when related with carbon dioxide given out by the tourist form calcium bicarbonate. I.e. calcium $+\mathrm{Co}_{2}$ Calcium bicarbonate. This calcium bicarbonate makes the surface loose and pigments fall. 
iii. The Humidity in the cave - when more visitors come the humidity increases. Dehumidifiers must be applied in the caves, set of double doors does not effect a lot. Tourist must not be allowed in the cave having paintings and are in the fragile state.

iv. The tapping and walking of the visitors have and effect on the paintings due to vibration which may cause a gradual effect on the paintings.

v. The guides comes along with the groups interpreting the tourist causes noise pollution in the cave. A study must be conducted with experts and the decibel level must be continuously checked of the visitors. The most scacitire paintings get shattered due to noise pollutions and has an adverse impact on it hence a standard must be introduced to save the paintings.

Hence taking into consideration the following aspects carrying capacity must be monitored at regular interval in accordance to the sensitive caves.

\section{Weathering}

In the rain shadow areas of the Deccan, there is heavy rain for the three months of the monsoon season, after which the climate is hot and dry. During the rainy season (which is, incidentally, one of the best times to visit Ajanta), the Waghora river cascades through seven hollows in the rock before it flows through the valley. Over millions of years, this passage sculpted out the gorge. The level of humidity is high which takes its toll on the paintings. There is also the natural wear and tear of the rock.

The agents of weathering like wind, water, temparature variations, climate, bio-organisms etc, have effected macro as well as micro structures in the rocks, to bring about a gradual deterioration in the rock mass quality. Grade ll weathering (slightly weathered rock) is seen in most of the exposures outside the caves while the rocks inside the caves are generally fresh and unweathered. Patches of moderately weathered basalt are seen in the toe portion of some caves and inter cave zones. The thickness of the weathered rim is $1-2 \mathrm{~m}$. Accentuated weathering is seen along unit contacts which has led to the destruction of many pillars.

\section{Seepage}

Seepage of water in the caves is restricted to the outer $2-3 \mathrm{~m}$ portion of the caves, Surface run off flowing down the slope permeates into the cracks causing seepage, Some water seepage is because of surface water roll back due to surface tension. Most of the paintings on walls that are up to a height of $2 \mathrm{~m}$ 
have been completely lost suggesting anthropogenic interference. Similarly sculptures below $2 \mathrm{~m}$ have lost details and in many cases the original form. Proper management and control of surface water would help in reducing the problem of water seepage. The measures listed below will provide for better control of surface water.

i. Repairing and water proofing of the existing drains and nalla beds on the slope over the caves.

ii. Construction of contour drainage and diversion of collected waters through connecting drains to the main nallas.

iii. Geosynthetic cover at places on the rock slope to prevent seepage. Polymer coating of the rock surface at places to arrest weathering.

iv. Provision of drainage holes in the saturated zone, shotcreting of the gaps creating over hangs.

v. Shotcreting and rock bolting of facades.

vi. Re-erection of damaged pillars to bear load where necessary.

vii. Toe support below caves (particularly below caves $1,2,17$ and 22).

viii. Strengthening of distressed pillars by micro stitching, encasement or epoxy / polymer grouting.

ix. Sealing of the rock / RCC interface area (cave 21).

$x$. Removal of boulders from the slopes over the caves. Flaxation of detached boulders by chain link and shotcreting at place.

xi. Fresh shotcreting after removal of old gunited layers.

xii. Removal of big trees located directly above the caves.

xiii. Improvement of the concealed channel on crown of back aisle of cave 1 .

\section{Air Pollution}

i. To avoid the air pollution, pollution free zone is there, where no vehicles other than the pollution free buses are used from the T-Point to the caves.

ii. Blasting near the cave sites is not allowed during construction.

iii. Areas prone to fugitive dust emissions are stabilized by spraying of water.

iv. Limits are also set on the maximum permissible emission from various types of vehicle engines and sources. 
There must be a continuous moniteration of the suspended particulates matter i.e. Nitrogen oxides, Carbon Monoxide, Hydrocarbons and Lead that may cause harm to the environment. The air pollution in the caves is also neglected which is discoursed in the conservational aspects i.e. regarding the respiration, foot tapping, micro-organisms humidity etc.

\section{Water Pollution}

Water pollution is least seen over here

i. Embankments are constructed for road bridges to prevent soil erosion.

ii. Water quality at source and distribution points should be regularly monitored to meet the standard of drinking water stipulated by the State Pollution Control Board.

iii. Sewerage network is well maintained and monitored.

\section{Noise Pollution}

i. Noise pollution is mainly seen in the caves which affect the paintings on a large scale. Continuous decibel count must be there taking into consideration the number of visitors to be allowed in the caves, and also the standard level of talking especially to the guides who interpret the paintings and also the tourist continuous monitoring again play a big deal to handle this problem.

ii. Tree belts must be planted which can act as noise buffer zone.

iii. Construction contract specification must contain guaranteed level of maximum noise emissions for various land use zones, according to the Noise Abatement Criteria specified by the Ministry of Environment and Forest.

\section{Conclusion}

The Ajanta - Ellora conservation and development project is a novel project which has developed the region, but there are certain problems of the environment on the caves which have been discussed in this paper. For overcoming these problems an integrated approach of both the organization and management of the various government and non-government agencies is required to decrease the environmental impacts on the caves. The Forest Department, MTDC, Archaeology, Experts, NGO's, Locals and Tourist must come together and form various committees for the Conservation of sculptures and paintings and the 
natural environment around the caves. The concept of scientific carrying capacity should be implemented.

\section{References}

1. Ramsharan Sharma - Ancient India, Delhi 1977.

2. Gupte R. S. - Iconography of the Buddhist Caves of Ellora, 1964

3. Frontline - Conservation Questions at Ajanta Vol 15, No. 23 November 1998.ASI - Ajanta Caves

4. Maharashtra Tourism Development Corporation Tourism Ajanta Ellora Development Plan Vol. 2.

5. Geoscientific Studies Conservation of Ajanta Caves. www.gsi.gov.in/a 